\title{
Nigella Sativa's Protection Against 7,12 Dimethylbenz [A] Anthracene -Induced Colon Carcinogenesis in Rats
}

\author{
Heny Ekowati*, Firster Nugroho, Iskandar Sobri \\ Pharmacy Department, Faculty of Health Sciences, Universitas Jenderal Soedirman, \\ Jl. Dr. Suparno, Karangwangkal, Purwokerto 53123, Indonesia \\ *Corresponding author email: heny.ekowati@unsoed.ac.id
}

Received November 25, 2020; Accepted Oktober 08, 2021; Available online November 15, 2021

\begin{abstract}
Colon cancer is the third most common cause of death from cancer worldwide. Recently, natural products have been widely used as an alternative therapy for colon cancer. Previous studies have reported that Nigella sativa has chemopreventive activity in vitro and in vivo. This study aimed to evaluate the effect of Nigella sativa seed (NSS) on rat-colon cell after initiation of 7,12-dimethylbenz [a] anthracene. Rats were divided into five groups, 12 rats in each group: Group I was given 7,12dimetilbenz [a] anthracene (DMBA) orally $20 \mathrm{mg} / \mathrm{kgBW}$ twice a week for five weeks, group V is the solvent control group was given corn oil. The other three groups were given DMBA + NSS, at the dosage of $250 \mathrm{mg} / \mathrm{kgBW}, 500$ $\mathrm{mg} / \mathrm{kgBW}$ and $750 \mathrm{mg} / \mathrm{kgBW}$. NSS extract was dissolved in corn oil and administered daily per oral during the next two weeks before and during the initiation of DMBA. After 16 weeks, all rats were sacrificed. H\&E staining showed that necrosis activity was lower in treated groups compared to DMBA group. AgNOR staining showed mAgNOR was significantly decrease following the increasing dose of NSS $(250 \mathrm{mg} / \mathrm{kgBW}, 500 \mathrm{mg} / \mathrm{kgBW}$ and $750 \mathrm{mg} / \mathrm{kgBW})$ were subsequently $1.62 \pm 0.086$, $1.60 \pm 0.101$ and $1.39 \pm 0.049(p<0.05)$. The results showed that NNS reduce the damage of colon cells and inhibit colon cell proliferation in DMBA induced rats.
\end{abstract}

Keywords: colon cancer, DMBA, Nigella sativa, rats

\section{INTRODUCTION}

Cancer is the second most common cause of death in the United States. In 2016, there were 9,678 new incidence of colon cancer, 6-7 people in 100,000 population died (Chu, 2018). Based on the data from the National Cancer Institute, the death rate from colon cancer is more than 33\% in 2012 (Brody, 2015). Cancer therapy consists of surgery, radiation and chemoterapy. Chemoterapy still has a lot of constrains, because the huge of side effects such as anemia, thrombocytopenia, neutropenia and severe pain (Vogel, Eskicioglu, Weiser, Feingold, \& Steele, 2017).

Currently, herbal is widely used as chemopreventive to help solve the problems as complementary drug for cancer therapy. One of medicinal plant is black cumin (Nigella sativa) (Dajani, Shahwan, \& Dajani, 2016). N. sativa contains $216 \mathrm{~g}$ protein, $406 \mathrm{~g}$ fat, $45 \mathrm{~g}$ ash, $84 \mathrm{~g}$ fiber, $249 \mathrm{~g}$ free nitrogen extract, $38 \mathrm{~g}$ moisture, $105 \mathrm{mg}$ iron, $18 \mathrm{mg}$ copper, $60 \mathrm{mg}$ zinc, $527 \mathrm{mg}$ phosphorus, 1. $860 \mathrm{mg}$ calcium, $15.4 \mathrm{mg}$ thiamin, $57 \mathrm{mg}$ niacin and $160 \mu \mathrm{g}$ folic acid per $\mathrm{kg}$. Also, studies have shown the presence of different active pharmaceutical ingredients in the N. sativa seeds (NSS), including thymoquinone, thymol, limonene, carvacrol, $p$ cymene, alpha-pinene, 4-terpineol, longifolene, and t-anethole benzene (Kooti, Hasanzadeh-Noohi, Sharafi-Ahvazi, Asadi-Samani, \& Ashtary-Larky, 2016). Thymoquinone is the main active constituent of the volatile oil of the $N$. sativa. The chemical composition of the black seed of Nigella sativa was found to contain a fixed oil (30\%) and a volatile oil that is average $0.5 \%$, maximum $1.5 \%$. The volatile oil was found to contain $54 \%$ thymoquinone and many monoterpenes such as p-cymene and a-pinene, dithymoquinone and thymohydroquinone (Haseena, Aithal, Das, \& Saheb, 2015).

In our previous study, cytotoxic activity of chloroform extract of NSS is higher than petroleum ether, alcohol and ethyl acetic extracts. The research suggests that chloroform is one of the semi-polar solvent commonly used to attract terpenoid compounds, phenols, and lipids (Harbone, 1998). Therefore, it is possible that thymoquinone largely attracted by the chloroform. The results obtained that the chloroform extracts of NSS have anticancer activity in vitro. Extract was said to have anticancer activity when the $\mathrm{IC}_{50}$ value of less than $1000 \mu \mathrm{g} / \mathrm{mL}$ after 24 $\mathrm{h}$ contact time. We continued to fractionated by column chromatography to separate the components of organic compounds in the sample. Hexane and chloroform were used with various comparisons and proceed according to different levels of polarity using 
the other solvent that was ethyl acetate and methanol. Elution process performed to form ribbons of yellow and brownish red in stationary phase. Analyzing of active compounds in fractions using GC-MS method obtained linoleic acid (55.6\%), oleic acid (23.4\%), palmitic acid $(12.5 \%)$ and tryptamine $(0.01 \%)$ in the chloroform extract of $N$. sativa seed (Ekowati, Rahmani \& Rastuti, 2011).

$N$. sativa can be used to inhibit carcinogenesis initiation and has protective against DNA damage caused by oxidative stress (Dajani et al., 2016). Nano emulsion of $N$. sativa's essential oil can inhibit cell proliferation of MCF-7 breast cancer cell (Periasamy, Athinarayanan, \& Alshatwi, 2016). The chloroform extract of $N$. sativa has cytotoxic activity on breast cancer T47D cells with IC 50 of $124 \mu \mathrm{g} / \mathrm{mL}$ (Ekowati et al., 2011). Our previous study also reported that NSS chloroform extract was capable of reducing cellular proliferation in DMBA-induced liver cancers in rats (Alisah, Baroroh \& Ekowati, 2012). An experimental study showed that orally administered of $N$. sativa had hepatoprotective effects against dimethylaminoazobenzene (DAB)-induced cholangiocarcinoma in male Swiss albino mice. $N$. sativa's essential oils injected into tumors grafted in DBA2 mice presumably showed either antimetastatic activity, or an inhibitory or delaying effect on metastasis through rapid reduction of primary tumor volume at the site of induction (Mohamed, El-Sayed, \& Moawad, 2010). Another study indicated that an ethanol extract of $N$. sativa effected a significant decrease in cell proliferation, DNA synthesis, mitosis and the extension of the percentage of live rats. The administration of $N$. sativa reduced the carcinogenic effects of DMBA in skin carcinoma, suggesting a protective effect (Mbarek et al., 2007) Thymoquinone as the active compound of $N$. sativa, suppresses the proliferation of renal cell carcinoma cells via reactive oxygen species-induced apoptosis (Liou et al., 2019). p53, NF-kB, PPARY, STAT3, MAPK, and PI3K/AKT signaling pathways are among the most significant pathways through which thymoquinone mediates its anti-cancer activity (Chen et al., 2017; Majdalawieh, Fayyad, \& Nasrallah, 2017).

This study aimed to observe the activity of NSS extract on 7,12 dimethylbenz [a] anthracene-induced colon carcinogenesis in rat through histopathology and AgNOR staining of the colon cells.

\section{EXPERIMENTAL SECTION Materials}

The chloroform extract of NSS, DMBA $(7,12$ dimetilbenz [a] anthracene) was obtained from Sigma (Saint Lovis, MO, cat.no D3254).

\section{Preparation of NSS-Chloroform Extract}

Nigella sativa seeds (NSS) are washed with water, dried and ground into powder. NSS powder were macerated using petroleum ether for $1 \times 24 \mathrm{~h}$. Extract was filtered and then evaporated by the evaporator.
Then the filtrate was continued macerated with chloroform, ethyl acetate, and ethanol respectively, each for $3 \times 24$ h. The extract is filtered and then evaporated. Chloroform extract was used in our in vivo experiments based on previous study (Ekowati et al., 2011), reported that the chloroform extract is the most active extract in T47D cancer cell line.

\section{Animals}

Sprague Dawley female rats weighed 100 to 150 grams were obtained from the Laboratory of Pharmacology and Toxicology, Faculty of Pharmacy, Universitas Gadjah Mada, Yogyakarta, Indonesia. The rats were kept for at least one week before use, provided with standard pellet diet and water ad libitum, and was kept on a 12:12 h light/dark cycle (Faculty of Medicine UGM-MHREC/Ref: $\mathrm{KE} / \mathrm{FK} / 575 / \mathrm{EC}, 2013)$.

An experimental study design was set up with post only control group design using rats. Rats were divided into five groups, 12 rats in each group: Group I, the control group was given DMBA orally $20 \mathrm{mg} / \mathrm{kgBW}$ twice a week for five weeks, group $V$ is the solvent control group was given corn oil. The other three groups were given DMBA + NSS, at the dosage of 250 $\mathrm{mg} / \mathrm{kgBW}, 500 \mathrm{mg} / \mathrm{kgBW}$ and $750 \mathrm{mg} / \mathrm{kgBW}$. NSS extract was dissolved in corn oil and administered daily per oral during the next two weeks before and during the initiation of DMBA. At the end of the experiment (16 week) all rats were sacrificed, observations of colonic cell proliferation was performed using hematoxylin and eosin staining (H\&E) and AgNOR. Data were analyzed using one-way ANOVA, followed by Tukey HSD. Body weight was recorded weekly throughout the study.

\section{H\&E Staining}

After 16 weeks all rats were sacrificed. At autopsy, the colon was removed and fixed in $10 \%$ buffered formalin. After 12-24 h of fixation, 3-5 $\mu \mathrm{m}$ tissue slices were embedded in paraffin, and stained with hematoxylin and eosin for microscopy examination.

\section{AgNOR Staining}

AgNOR staining was performed according to the modified method (D'Uva, Baci, albini, \& Noonan, 2018; Kilari, Kotakadi, \& Penchalaneni, 2016). The staining solution was prepared by mixing one part of $2 \%$ gelatin in $1 \%$ formic acid with two parts of $50 \%$ aqueous silver nitrate. All sections were cut to $3 \mu \mathrm{m}$ in thickness from routinely processed paraffin blocks. Sections were immersed in sodium citrate buffered $(\mathrm{pH}$ 6.0) and incubated $20 \mathrm{~min}$ in autoclave $\left(120^{\circ} \mathrm{C}, 1.1\right.$ 1.2 Bar). Sections were then covered with the AgNOR staining solution at room temperature in the dark for 15-20 min. The specimens were then washed with $5 \%$ sodium thiosulfate and distilled deionized water, dehydrated through graded ethanol to xylene, and mounted in synthetic medium.

AgNORs, which are appeared as dots both outside and within the nucleoli, were counted according to the 
description of previous report (Gholamnezhad, Havakhah, \& Boskabady, 2016). A minimum one hundred cells per specimen were observed randomly in three different views using High Power Field (HPF). Mean value of AgNOR (mAgNOR) was used as a parameter to evaluate antiproliferative activity. $\mathrm{mAgNOR}$ is a mean of black dots in a cell, computed from total amount of blackdots ( $\mathrm{min} 100$ cells) divided with amount of cells (min 100 cells) (Kilari et al, 2016). All specimens were observed by two observer on a binocular microscope (Olympus ${ }^{\circledR}$ DP1 2 microscope digital camera system, NY) with an immersion oil lens at magnification of 1000x.

\section{Statistical analysis}

A statistically significant body weight and $\mathrm{mAgNOR}$ score difference were evaluated by ANOVA, continued by HSD $(p<0.05)$ using SPSS ver. 18.

\section{RESULTS AND DISCUSSION}

The NSS extract was prepared by maceration method. Maceration is a method to prepare extract by using appropriate solvent with several times shaking or stirring at room temperature. Maceration suitable for compounds that do not withstand heating at high temperatures. The aim is to attract the chemical components based on the principle of mass transfer of substance into the solvent component, where the movement began to occur at the interface layer and then diffuses into the solvent (Anonymous, 2011).

Petroleum ether is a non-polar solvent used to attract non-polar compounds such as wax, fat and lipids which can interfere during the separation process. In addition, petroleum ether was used to eliminate the resins which can interrupt the extraction. After the filtrate macerated with petroleum ether, macerate aerated and then macerated with chloroform for $3 \times 24 \mathrm{~h}$. Chloroform is one of the semi-polar solvent commonly used to attract terpenoid compounds, polyphenols, fatty acids, fats, oils, essential oils, phenols and lipids (Harbone, 1998). The study reported that potential as an anticancer compound from the extract is thymoquinone. Thymoquinone was a component of essential oil (Haseena, Aithal, Das, \& Saheb, 2015).

\section{Effect of DMBA on body weight female rats}

There was no direct evidence of toxicity due to NSS treatment. Body weight changes of the animal treated with corn oil, DMBA and DMBA+NSS were compared (Table 1). In the beginning of the study, the body weight of corn oil group was different from the other groups $(p<0.05)$. Final body weight showed that DMBA goup was no significant different from DMBA+NSS groups $(p>0.05)$ (Table 1). This showed us that there is no toxicity due to NSS treatment related to body-reducing weight as we could find in the treatment of an anticancer drugs (Chu, 2018). Previous study, showed that the chloroform extract of NSS had cytotoxic activity on breast cancer cells T47D, with $\mathrm{IC}_{50}$ value $161.131 \mu \mathrm{g} / \mathrm{mL}$ (Ekowati et al., 2011). Our study aimed to asses the effect of NSS chloroform extract on DMBA induced rat colon cancer. In this study, extract chloroform of NSS was given two weeks before and during induction of DMBA (Figure 1).

\begin{tabular}{|c|c|c|c|c|c|c|c|c|c|c|c|c|c|c|}
\hline & \multicolumn{14}{|c|}{ Weeks } \\
\hline & $\begin{array}{ll}1 & 2 \\
\end{array}$ & 3 & 4 & 5 & 6 & 7 & 8 & 9 & 10 & 11 & 12 & 13 & 14 & 15 \\
\hline G. I & & & & & 8 & 3 & & & & & & & & \\
\hline G. II & $\$ \alpha$ & & & & & & & & & & & & & \\
\hline G. III & $8 \% 8$ & & & & & & & & & & & & & $\mathbb{\$}$ \\
\hline G. IV & 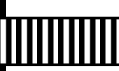 & |l|| & IIII & |l| & |lा & & & & & & & & & $\mathbb{N}$ \\
\hline G. V & & & & & & & & & & & & & & $\mathbf{\$}$ \\
\hline
\end{tabular}

DMBA Group (20 mg/KgBW)
DMBA (20 mg/KgBW) group + NSS $250 \mathrm{mg} / \mathrm{KgBW}$
DMBA (20 mg/KgBW) group + NSS $500 \mathrm{mg} / \mathrm{KgBW}$
DMBA (20 mg/KgBW) group + NSS $750 \mathrm{mg} / \mathrm{KgBW}$
Corn oil group

Figure 1. Experimental time line. NSS extract prevents directly the metabolic activation of DMBA, prevent tissue damage and also prevent cancer carcinogenesis at the initiation stage. 
Table 1. Effect of DMBA on body weight

\begin{tabular}{llc}
\hline Groups & \multicolumn{1}{c}{$\begin{array}{c}\text { Body weight in the } \\
\text { beginning of experiment }(\mathrm{g})\end{array}$} & $\begin{array}{c}\text { Body weight in the } \\
\text { end of experiment }(\mathrm{g})\end{array}$ \\
\hline DMBA & $90.00 \pm 15.37$ & $121.43 \pm 68.95$ \\
$\mathrm{DMBA}+\mathrm{N}$. sativa $250 \mathrm{mg} / \mathrm{Kg} \mathrm{BB}$ & $90.00 \pm 20.45$ & $112.00 \pm 58.98$ \\
$\mathrm{DMBA}+\mathrm{N}$. sativa $500 \mathrm{mg} / \mathrm{Kg} \mathrm{BB}$ & $78.33 \pm 17.49$ & $121.43 \pm 63.88$ \\
DMBA + N. sativa $750 \mathrm{mg} / \mathrm{Kg} \mathrm{BB}$ & $64.17 \pm 15.05^{*}$ & $82.00 \pm 46.21^{*}$ \\
Corn oil & $54.17 \pm 9.00^{*}$ & $90.00 \pm 35.71^{*}$
\end{tabular}

Values are expressed as mean $\pm S D ; n=12, *$ When compared with DMBA Group, Statistical significance different: $p<0.05$

\section{Histopathological Studies of Colon}

Histopathology profile of colon cell of DMBA and DMBA+NSS treated rats is depicted in Figure 2. At autopsy, colon organ were removed and fixed in 10\% buffered formalin. As thick as 3-5 $\mu \mathrm{m}$ tissue slices were embedded in paraffin, and stained with hematoxylin and eosin. In general, hematoxylin and eosin staining showed differences in morphology between DMBA+NSS and DMBA. DMBA group showed necrosis cells in the colon more severe than DMBA+NSS groups.

Our previous study showed that treatment of extract NSS $750 \mathrm{mg} / \mathrm{kgbw}$ significantly decreased proliferation of colon cells induced by DMBA, which in line with the result of the study by Andini, Baroroh, and Ekowati (2013) on renal cells. Treatment of NSS extract can induce the expression of p53 protein in WiDr cell with $\mathrm{IC}_{50} 3.31 \mu \mathrm{g} / \mathrm{mL}$. Antiproliferative activity of extract chloroform of NSS is mediated by metabolic enzyme CYP and glutathione S-transferase (GST) (Darakhshan, Bidmeshki, Hosseinzadeh, and Sisakhtnezhad, 2015). DMBA needs to be metabolized to become a reactive metabolite. DMBA is a substrate of the enzyme cytochrome P450 (CYP), CYP1A1 and CYP1B1 (Kilari et al., 2016). After metabolized, DMBA will produce ultimate carcinogens, dihydrodiol epoxide and radical cation that are highly reactive (D'Uva et al., 2018). The epoxide metabolite also interact with GST to generate glutathione conjugates that are readily metabolized to the mercapturic acid and will be eliminated from the body (Gholamnezhad et al., 2016).
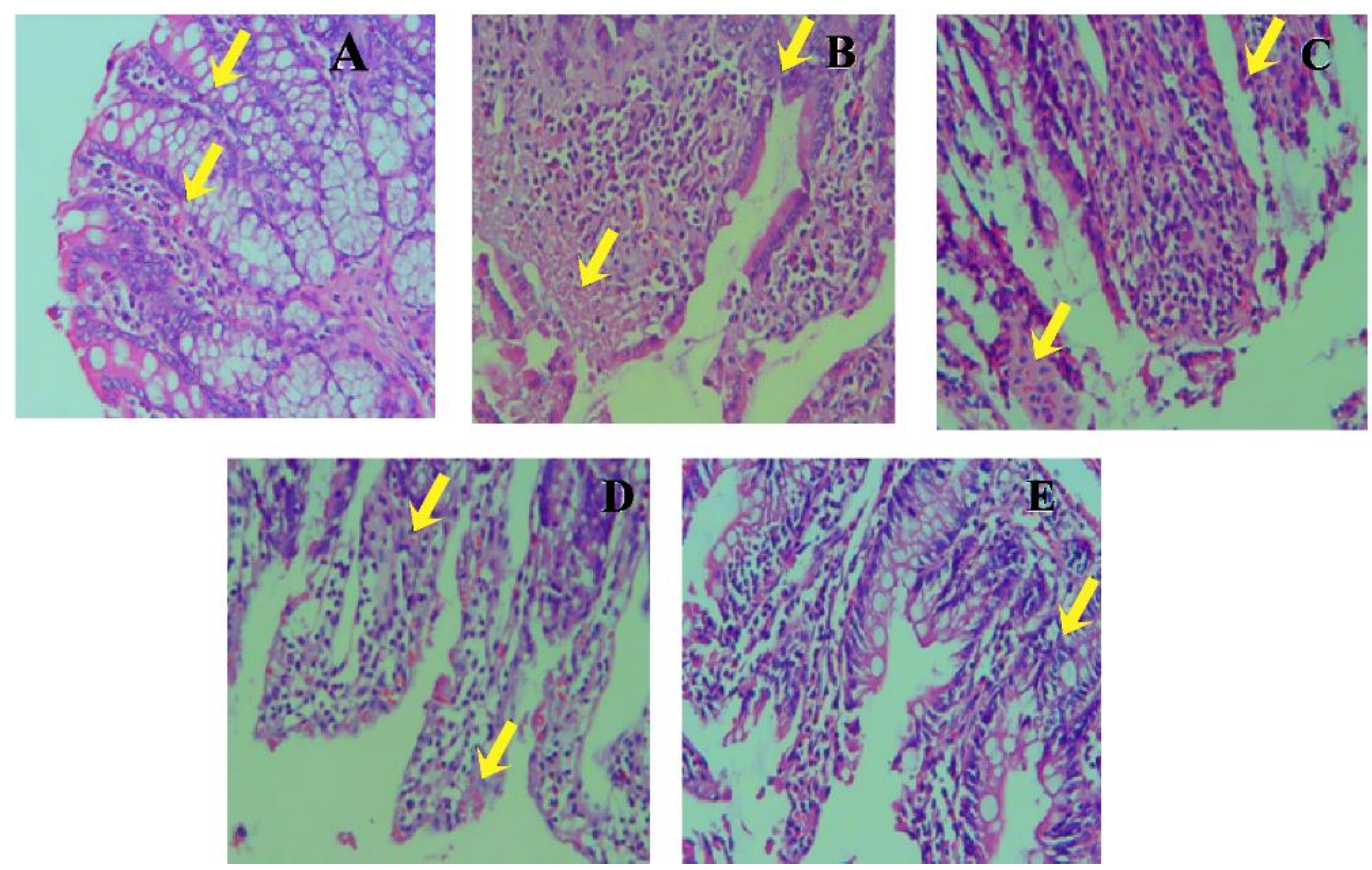

Figure 2. Histological evaluation in colon tissues of control and experimental group. Rats were divided into 5 groups, (A) Corn oil, (B) DMBA control group $(20 \mathrm{mg} / \mathrm{kgBW}$ in Corn oil), (C) DMBA+ NSS $250 \mathrm{mg} / \mathrm{kgBW}$; (D) DMBA+ NSS $500 \mathrm{mg} / \mathrm{kgBW}$, (E) DMBA+750 NSS mg/kgBW. ( $\uparrow=$ necrosis). Magnification $\times 600$. 
Antiproliferative Activity of NSS on Female Rats Colon AgNOR staining on solven colon (Figure 3) showed that DMBA group has higher blackdots than the other groups. Cancers have a high proliferation rate that is closely related to the amount of argyrophilic proteins (AgNOR proteins) in the nucleolar organizer regions (NORs). The nucleolar organizer regions which are DNA loops located on acrocentric chromosomes responsible for their synthesis. AgNOR proteins are visualized as black-brown dots by their binding to silver nitrate according the AgNOR method. A higher AgNOR count indicates a correspondingly higher proliferation rate (as in cancer cells), and conversely, a lower proliferation rate (as in normal cells) is shown by a low AgNOR count. Our study was to evaluate the activity of a chloroform extract of NSS extract on 7,12 dimethylbenz [á] anthracene (DMBA)-induced colon carcinogenesis in rats by examination with silverstaining by the AgNOR method.

At autopsy, colon organ were removed and fixed in $10 \%$ buffered formalin. As thick as 3-5 $\mu \mathrm{m}$ tissue slices were embedded in paraffin, and stained with $\mathrm{AgNO}_{3}$. Argyrophilic Nucleolar Organiser Regions (AgNORs) are visible as dark dots within the plasma cell nuclei.
The scores of mAgNOR (Table 2) of corn oil and DMBA are $1.26 \pm 0.13$ and $1.63 \pm 0.06$ respectively.

Treatments of NSS at the dosage of $250 \mathrm{mg} / \mathrm{kgBW}$, $500 \mathrm{mg} / \mathrm{kgBW}$ and $750 \mathrm{mg} / \mathrm{kgBW}$ showed significant antiproliferative activity of DMBA (Table 2) with $\mathrm{mAgNOR}$ scores $1.62 \pm 0.09,1.60 \pm 0.10$, and 1.39 \pm 0.05 ( $p<0.05)$ respectively. This result is in line with our previous study, the NSS chloroform extract was capable of reducing cellular proliferation in DMBA-induced liver cancers in rats (Alisah et al., 2012). NSS treatment was designed to prevent metabolic activation of DMBA and suppress liver cancer progression. The liver is exceedingly vulnerable to damage by chemical carcinogens, which is thought to result from its central role in the metabolism of foreign substances (xenobiotics), including potential carcinogens DMBA is a polycyclic aromatic hydrocarbon (PAH) carcinogen that is oxidized to 7,12-DMBA-3,4-oxide by cytochrome P450 enzymes (CYPs), then hydrolyzed to its corresponding diol and finally oxidized by CYPs to 7,12-DMBA-3,4-oxidediol-1,2-epoxide, which is the ultimate carcinogen. Individual PAHs may affect their own metabolism, which is catalyzed by CYP $1 \mathrm{~A} 1$, 1A2, and 1B1 (Shimada and Kuriyama, 2004).
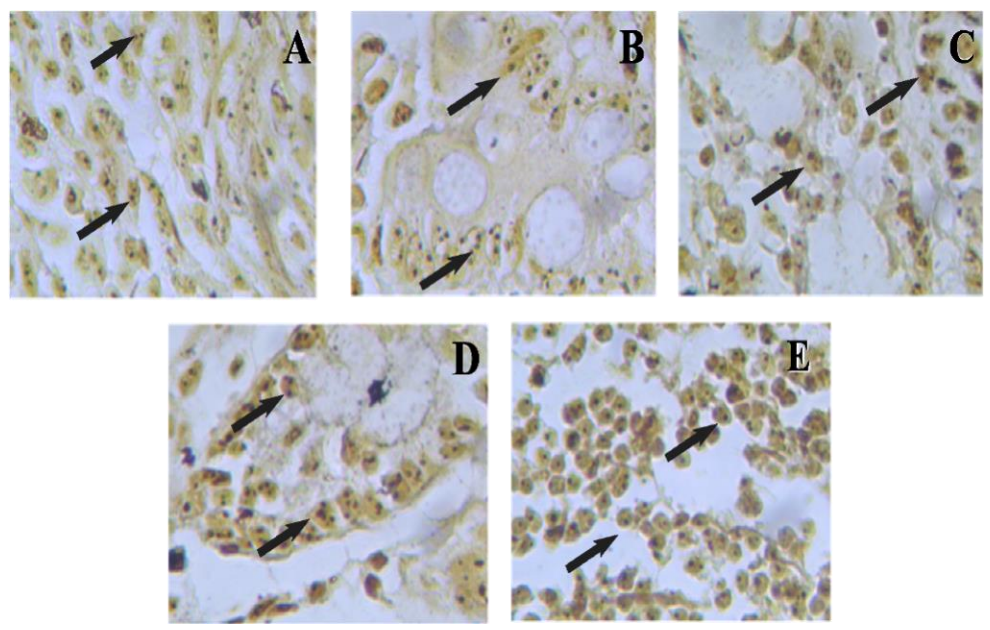

Figure 3. AgNO3 stained colon tissues of control and experimental group. Rats were divided into 5 groups, (A) Corn oil, (B) DMBA control group $(20 \mathrm{mg} / \mathrm{kgBW}$ in Corn oil), (C) DMBA+ NSS 250 $\mathrm{mg} / \mathrm{kgBW}$; (D) DMBA+ NSS $500 \mathrm{mg} / \mathrm{kgBW}$, (E) DMBA+ NSS $750 \mathrm{mg} / \mathrm{kgBW}$. Argyrophilic Nucleolar Organiser Regions (AgNORs), pointed by black arrow. Magnification x1000

Table 2. Effect of $N$. sativa on proliferation of DMBA-induced colon female rats

\begin{tabular}{lc}
\hline Group Rats & mAgNOR \\
\hline DMBA & $1.63 \pm 0.06$ \\
DMBA + NSS $250 \mathrm{mg} / \mathrm{Kg} \mathrm{BB}$ & $1.62 \pm 0.09$ \\
DMBA + NSS $500 \mathrm{mg} / \mathrm{Kg} \mathrm{BB}$ & $1.60 \pm 0.10$ \\
DMBA + NSS $750 \mathrm{mg} / \mathrm{Kg} \mathrm{BB}$ & $1.39 \pm 0.05^{*}$ \\
Corn oil & $1.26 \pm 0.13^{*}$
\end{tabular}

$\mathrm{mAgNOR}=$ mean $\mathrm{AgNOR}, *$ are statistically significant different from DMBA groups $(p<0.05)$ by one way Anova continued with Tukey HSD. 
In general, treatment of NSS inhibit proliferation of colon cells in rats induced with DMBA. Fractionation of the NSS chloroform extract yields linoleic and palmitic acids, and an indole compound which is an alkaloid that is tryptamine (Ekowati et al., 2011). The linoleic acid content of NSS seeds can inhibit cell proliferation. Linoleic acid reduces cancer cell proliferation in lung, breast, prostate and colon cancers. The linoleic and palmitic acid content of NSS has antiproliferative activity by induction of apoptosis in liver cells (Zhang, Xue, Zhang, Yang, \& Shi, 2012). Linoleic acid (omega-3) and á-linoleic acid (omega-6) can influence gene expression in experimental animals, have antiinflammatory activity, and can suppress interleukin-1 â (IL-1â), tumor necrosis factor-á (TNFá) and interleukin-6 (IL-6) Linoleic acid can enhance the expression of pro-apoptotic genes such as Bax and can reduce expression of anti-apoptotic genes such as $\mathrm{Bcl}-2$, which finally will activate caspase 3 and 9 pathway and enhance apoptosis. Linoleic acid has also been known to induce the activity of the p53 gene (Mericli et al., 2017; Zhang et al., 2015; Lu, Yu, Ma, Shen, \& Das, 2010). p53 gene was a regulatory protein which trigger the expression of CKI (p21), resulting in stops of cell cycle at G1 phase. N.sativa stimulates apoptosis by increasing p53 expression (Kotowski et al., 2017).

While palmitic acid induces reactive oxygen species (ROS), which will oxidizing the mitochondrial membrane and would disrupted the mitochondrial membrane potential, give the pores (Liv et al., 2018). Pore would facilitate the entry of calcium, releasing cytochrome c. Cytochrome will bind Apaf-1 and activating procaspase-9 become caspase-9. Caspase9 will excite caspase 3 to break down cell protein like cytoskeleton, enzyme and chromosomes (Fouad and Aanei, 2017).

Based on H\&E and mAgNOR data, there is relationship between histopathology of cell and antiproliferative activity. The lower cell damage and necrosis, the higher anti-proliferative activity will be. This may be caused by linoleic acid activity of the NSS chloroform extract, that suppress the expression of bcl2 , then suppress COX-2 and the activity of proinflammatory cytokines (TNF- $\alpha$, IL-6 and IL-1) (Da Boit, Hunter, \& Gray, 2017).

\section{CONCLUSIONS}

It is conclude that chloroform extract of N.sativa seeds is able to reduce cell proliferation of DMBAinduced colon in rats, subsequently the chloroform extract of $N$. sativa is potential to be developed as chemopreventive agent.

\section{REFERENCES}

Alisah, N. F., Baroroh, H. N., Ekowati, H. (2012). Protective effects of Nigella sativa against 7,12dimethylbenz [á] anthracene (DMBA) induced carcinogenesis in rats. Universa Medicina, $31(2), 88-95$.

Andini, D.A., Baroroh, H.N., Ekowati, H. (2013). Protective effects of Nigella sativa against carcinogenesis in renal rat cell induced 7.12dimetilbenz(a)anthracene (DMBA). Jurnal Ilmu Kefarmasian Indonesia, 11 (1), 76-82.

Anonymous (2011). Farmakope Herbal Indonesia. Departemen Kesehatan Republik Indonesia. Jakarta

Brody, H. (2015). Colon cancer. Nature, 521 (7551), S1.

Chen, M. C., Lee, N. H., Hsu, H. H., Ho, T. J., Tu, C. C., Chen, R. J., Lin, Y. M., Viswanadha, V. P., Kuo, W. W., Huang, C. Y. (2017). Inhibition of NF-KB and metastasis in irinotecan (CPT-11)resistant LoVo colon cancer cells by thymoquinone via JNK and p38. Environmental Toxicology, 32(2), 669-678. https://doi.org/10.1002/tox.22268.

Chu. E. (2018). Cancer chemotherapy. In Katzung B.G (Eds.), Basic and Clinical Pharmacology. (pp. 948-976). New York, Mc Grawhill.

Da Boit, M., Hunter, A. M., Gray, S. R., (2017). Fit with good fat? The role of $n$ 3 polyunsaturated fatty acids on exercise perfo rmance. Metabolism, 66, 45-54. http://dx.doi.org/10.1016/j.metabol.2016.10. 007.

Dajani, E. Z., Shahwan, T. G., Dajani, N. E. (2016). Overview of the preclinical pharmacological properties of Nigella sativa (black seeds): a complementary drug with historical and clinical significance. Canadian Journal of Physiology and Pharmacology, 67(6), 801-817.

Darakhshan, S., Bidmeshki, P.A., Hosseinzadeh C.A., Sisakhtnezhad, S. (2015). Thymoquinone and its therapeutic potentials. Pharmacological Research, 95-96, 138-58. https://doi.org/10.1016/i.phrs.2015.03.011.

D'Uva, G., Baci, D., Albini, A., Noonan, D.M. (2018). Cancer chemoprevention revisited: Cytochrome P450 family $1 \mathrm{~B} 1$ as a target in the tumor and the microenvironment. Cancer Treatment Reviews, 63, 1-18. DOI: https://doi.org/10.1016/i.ctrv.2017.10.013.

Ekowati, H., Rahmani, E.P.N., Rastuti, U. (2011). The Active Fraction From Nigella sativa and its activity against T47D cell line. Indonesian Journal of Chemistry, 11 (3), 217-22.

Fouad, Y.A., Aanei, C. (2017). Revisiting the hallmarks of cancer. American Journal of Cancer Research, 7(5), 1016-1036.

Gholamnezhad, Z., Havakhah, S., Boskabady, M. H. (2016). Preclinical and clinical effects of Nigella sativa and its constituent, thymoquinone: $A$ review. Journal of Ethnopharmacology, 190,372-86.

https://doi.org/10.1016/i.jep.2016.06.061 
Haseena, S., Aithal, M., Das, K. K., Saheb, S. H. (2015). Phyto chemical analysis of Nigella sativa and its effect on reproductive system. Journal of Pharmaceutical Science and Research, 7(8), 514-517.

Harbone, J.B. (1989). Phytochemical Methods: A Guide to Modern Ways of Analyzing Plants, ITB, Bandung.

Kilari, B.P., Kotakadi, V.S., Penchalaneni, J. (2016). Anti-proliferative and apoptotic effects of Basella rubra (L.) against 1, 2-dimethyl hydrazine-induced colon carcinogenesis in rats. Asian Pacific Journal for Cancer Prevention, 17(1), 73-80. DOl:http://dx.doi.org/10.7314/APJCP.2016.1 7.1.73.

Kooti, W., Hasanzadeh-Noohi, Z., Sharafi-Ahvazi, N., Asadi-Samani, M., Ashtary-Larky, D. (2016). Phytochemistry, pharmacology, and therapeutic uses of black seed (Nigella sativa). Chinese Journal of Natural Medicine, 14(10),732-745. doi: 10.1016/S1875-5364(16)30088-7.

Kotowski, U., Heiduschka, G., Kadletz, L., Fahim, T., Seemann, R., Schmid, R., Schneider, S., Mitterbaver, A., Thurnher, D. (2017). Effect of thymoquinone on head and neck squamous cell carcinoma cells in vitro: Synergism with radiation. Oncology Letters, 14(1), 1147-1151. DOI: 10.3892/ol.2017.6189.

Liou, Y. F., Chen, P. N., Chu, S. C., Kao, S. H., Chang, Y. Z., Hsieh, Y. S., Chang, H. R. (2019). Thymoquinone suppresses the proliferation of renal cell carcinoma cells via reactive oxygen species-induced apoptosis and reduces cell stemness. Environmental Toxicology. 34(11), 1208-20. doi: 10.1002/tox.22822.

Liu, T., Chen, X.M., Sun, J.Y., Jiang, X.S., Wu, Y., Yang, S., Huang, H.Z., Ruan, X.Z., Du, X.G. (2018). Palmitic acidinduced podocyte apoptosis via the reactive oxygen species-dependent mitochondrial pathway. Kidney and Blood Pressure Research, 43(1), 206-219. DOI: 10.1159/000487673.

Lu, X., Yu, H., Ma, Q., Shen, S., Das, U.N. (2010). Linoleic acid suppresses colorectal cancer cell growth by inducing oxidant stress and mitochondrial dysfunction. Lipids in Health and Disease, 9, 10-13.

Majdalawieh, A. F., Fayyad, M. W., Nasrallah, G. K. (2017). Anti cancer properties and mechanisms of action of thymoquinone, the major active ingredient of Nigella sativa. Critical Reviews in Food Science and Nutrition, 57(18), 39113928.

https://doi.org/10.1080/10408398.2016.127 7971.

Mericli, F., Becer, E., Kabadayı, H., Hanoglu, A., Yigit, H.D., Ozkum, Y.D., Ozek, T., Vatansever, S. (2017). Fatty acid composition and anticancer activity in colon carcinoma cell lines of Prunus dulcis seed oil. Pharmaceutical Biology, 55(1), 1239-1248. http://dx.doi.org/10.1080/13880209.2017.1 296003.

Mbarek, L.A., Mouse H.A., Elabbadi, N., Bensalah, M., Gamouh, A., Aboufatima, R., et al. (2007). Anti-tumor properties of blackseed (Nigella sativa L.) extracts. Brazilian Journal of Medical and Biological Research, 40, 839-47

Mohamed, H.A., El-Sayed, I.H., Moawad, M. (2010) Protective effect of Nigella sativa seeds against dimethylaminoazobenzene (DAB) induced liver carcinogenesis. Natural Science, 8, 80-87.

Periasamy, V. S., Athinarayanan, J., Alshatwi, A. A. (2016). Anticancer activity of an ultrasonic nanoemulsion formulation of Nigella sativa $L$. essential oil on human breast cancer cells. Ultrasound Sonochemistry, 31,449-55. https://doi.org/10.1016/j.ultsonch.2016.01.0 35.

Shimada, T., Kuriyama F. Y. (2004) Metabolic activation of polycyclic aromatic hydrocarbons to carcinogens by cytochromes P450 1A1 and 1B1. Cancer Science, 95, 1-6.

Vogel, J. D., Eskicioglu, C., Weiser, M. R., Feingold, D. L., Steele, S. R. (2017). The American society of colon and rectal surgeons clinical practice guidelines for the treatment of colon cancer. Diseases of Colon and Rectum, 60(10), 9991017. 10.1097/DCR.0000000000000926.

Zhang, Y., Xue, R., Zhang, Z., Yang, X., Shi, H. (2012). Palmitic and linoleic acids induce ER stress and apoptosis in hepatoma cells. Lipids in Health and Disease, 11, 1-8

Zhang, C., Yu, H., Shen, Y., Ni, X., Shen, S., Das, U.N. (2015). Polyunsaturated fatty acids trigger apoptosis of colon cancer cells through a mitochondrial pathway. Archives and Medical Science $17(5)$, 1081-94.

DOI: 10.5114 /aoms. 2015.54865 